\title{
IAMJ
}

INTERNATIONAL

AYURVEDIC

MEDICAL JOURNAL

\section{A SINGLE CASE STUDY ON EFFECT OF LAKSHADI CHOORNA KARNADOOPANA IN OTOMYCOSIS ASSOCIATED WITH OTITIS MEDIA}

\author{
Chaya $C^{1}$, Rathi $S^{2}$, S M. Pasha ${ }^{3}$
}

${ }^{1}$ Final year PG scholar dept of Shalakya Tantra. GAMC, Bengaluru, Karnataka, India

${ }^{2}$ Associated professor of dept of Shalakya Tantra, GAMC, Bengaluru, Karnataka, India

${ }^{3}$ Associated professor and HOD of dept of Shalakya Tantra. GAMC, Bengaluru, Karnataka, India

Corresponding Author: chayaambika@gmail.com

https://doi.org/10.46607/iamj5308102020

(Published online: October 2020)

Open Access

(C) International Ayurvedic Medical Journal, India 2020

Article Received: 30/05/2020 - Peer Reviewed: 14/06/2020 - Accepted for Publication: 25/09/2020

\section{Check for updates}

\section{ABSTRACT}

Otomycosis is a common condition encountered in a general otolaryngology clinic setting and has typically been described as fungal infection of the external auditory canal with frequent complications involving the middle ear. Although rarely life threatening, the disease is a challenging and frustrating entity for both patients and otolaryngologists as it frequently requires long-term treatment and follow-up. Despite this, there could be recurrences. Karnasrava is a disease mentioned by Acharya Sushruta in the chapter of Karnaroga Vigyaniya under twentyeight Karnarogas. Karnasrava is the condition characterized by discharge from Karna and occurs mainly due to Avarana of Vata Dosha. Otomycosis being one of the causes of Karnasrava was selected for the study. Treatment of Karnasrava is explained by Sushruta i.e. Karnadoopana, Karnapoorana, Prakshaalana etc.

Case Study: This is a case report of 50-year-old female patient who had complains of pain in right ear since 1 month associated with watery discharge from right ear. The subject is a known case of diabetic mellitus since 1year. The Otoscopic examination of bilateral ear, confirmed that, diagnosis of right ear was Otomycosis associated with otitis media. 
Materials and Method: The subject who approached Shalakya tantra OPD of GAMC with symptoms of right ear pain associated with on and off watery discharge was systematically reviewed. Intervention was planned for Doshic component involved in Karnasrava.

Result: The subject showed considerable improvement in right ear.

Discussion: Karnasrava is the condition characterized by Srava from Karna and occurs mainly due to Avarana of Vata Dosha. Otomycosis is a fungal infection of external auditory canal and one of the causes for Karnasrava. This study sheds light on holistic treatment like Karnadoopana told in the Ayurvedic classics.

Keywords: Otomycosis, Otitis media, Karnasrava, Karnadoopana, External auditory canal.

\section{INTRODUCTION}

Otomycosis or fungal otitis externa has typically been described as fungal infection of the external auditory canal with frequent complications involving the middle ear. Although rarely life threatening, the disease is a challenging and frustrating entity for both patients and otolaryngologists as it frequently requires longterm treatment and follow-up. Despite this, there could be recurrences.

Otomycosis is one of the common conditions encountered in a general otolaryngology clinic setting and its prevalence has been quoted to range from $9 \%{ }^{(1)}$ to $27.2 \%{ }^{(2,3)}$ among patients who present with signs and symptoms of otitis externa and up to $30 \%{ }^{(4)}$ in patients with discharging ears. It is worldwide in distribution with a higher prevalence in the hot, humid, and dusty areas of the tropics and subtropics ${ }^{(6)}$. Overview of the literature reveals Otomycosis to be a common medical problem in India ${ }^{(7)}$.

Fungi can either be the primary pathogen or be superimposed on bacterial infections. Most patients suffering from early Otomycosis complain of severe itching which often progress to pain, hearing loss, and often leading to tympanic membrane perforations ${ }^{(8)}$.

Although Aspergillus Niger and Candida albicans are by far the most common offenders ${ }^{(9)}$, a wide spectrum of other fungi can cause Otomycosis. Various factors have been proposed as predisposing factors for Otomycosis, including a humid climate, presence of cerumen, instrumentation of the ear, immunocompromised host, and, more recently, increased use of topical antibiotic/steroid preparations.

Diagnosis is mostly clinical, and Aspergillus and Candida species are the most commonly identified fungal pathogens. ${ }^{(10)}$ Fungal pathogens have been reported to cause $9 \%$ of all cases of otitis externa, but this figure appears to be on the rise, presumably because of the increased use of topical antibiotics. ${ }^{(11)}$

An infrequently reported complication of Otomycosis is tympanic membrane perforation. ${ }^{(12)}$ Karnasrava is a disease mentioned by Acharya Sushruta in the chapter of Karnaroga Vigyaniya under twentyeight Karnarogas. $\quad{ }^{(13)}$ Acharya Chara$k a$ included Karnasrava as a symptom under the four types of Karnarogas due to vitiation of different Dosha. ${ }^{(14)}$

Karnasrava is one of symptom of Otomycosis. In Vrana srava Vigyaniya Adhyaya, Acharya Sushruta has described many types of Srava. Out of them Twakagata and Mamsagata Srava is in similar with modern Otomycosis. ${ }^{(15)}$ The general line of treatment of Karnasrava is Shirovirechana, Dhoopana, Karnapoorana, Pramaarjana, Dhaavana, Prakshaalana etc. ${ }^{(16)}$

In Otomycosis, frequent cleaning of external auditory canal either by suction, evacuation or by syringing, followed by moping are advised which are very similar to Ayurvedic line of treatment of Karnasrava. Further topical medications are applied as disinfectant, anti-inflammatory and antifungal ${ }^{17}$.

In modern times, many treatments are there, but it is having side effects like burning sensation, stinging sensation etc. The treatment of this particular disease has never been satisfactory and therefore, a number of treatments were advised to relieve this condition. So, to overcome above problems there is a need to find 
cheaper and easily available Ayurvedic medicine. In the present study Karnadoopana with Lakshadi choorna and internally Chitrakadi harithaki lehya, Lakshadi guggulu and Sarivadi Vati were selected.

\section{A CASE STUDY}

Date of Visit-7/7/2019

Chief Complaints- pain in right ear and watery discharge on and off since 1 month.
History of present illness: Patient was apparently normal before 1month back, later she developed pain in right ear with discharge on and off. Then she consulted to our hospital on 7/7/2019. Ayurvedic management was carried out after detailed assessment of her bilateral ear examination and history.

Past History - Nothing significant.

Table 1: On examination (before treatment)

\begin{tabular}{|l|l|l|}
\hline & Right ear & Left ear \\
\hline Pinna & Normal & Normal \\
\hline Prearicular area & Normal & Normal \\
\hline Post auricular area & Normal & Normal \\
\hline External auditory canal & Otomycosis & Normal \\
\hline Tympanic membrane & Central perforation & Normal \\
\hline Mastoid & Non tenderness & Non tenderness \\
\hline Nose examination & Normal & Normal \\
\hline Paranasal sinus & Normal & Normal \\
\hline
\end{tabular}

Oropharynx -normal

Oral cavity -normal

Treatment given

Yoga is Anubhutha yoga, there is no direct reference of Lakshadi choorna Karnadoopana but Lakshadi choorna contains drugs are antibacterial, antimicrobial and Anti-inflammatory.

\begin{tabular}{|c|c|c|}
\hline $\begin{array}{l}1^{\text {st }} \text { sitting } \\
(7 / 7 / 2019 \text { to } 13 / 7 / 2019)\end{array}$ & $\begin{array}{l}\text { 1. Cleaning of fungal growth with help of jobson probe. } \\
\text { 2. Karnadoopana with Lakshadi choorna (Laksha, Nimba, Guggulu, Haridra). } \\
\text { 3. Tab. Sarivadi Vati-(1-1-1) After food. } \\
\text { 4. Tab. Lakshadiguggulu (1-1-1) After food } \\
\text { 5. Chitrakadi harithaki lehya (1tsp-0-1tsp) After food }\end{array}$ & $\begin{array}{l}7 \text { days } \\
7 \text { days } \\
7 \text { days } \\
7 \text { days } \\
15 \text { days }\end{array}$ \\
\hline $\begin{array}{l}2^{\text {nd }} \text { sitting } \\
(7 / 8 / 2019 \text { to } 13 / 8 / 2019)\end{array}$ & $\begin{array}{l}\text { 1. Karnadoopana with Lakshadi choorna. } \\
\text { 2.Lakshadi guggulu (1-1-1) After food } \\
\text { 3. Tab. Sarivadi Vati-(1-1-1) After food. } \\
\text { 4.Chitrakadi harithaki lehya (1tsp-0-1tsp) After food }\end{array}$ & $\begin{array}{l}7 \text { days } \\
7 \text { days } \\
7 \text { days } \\
15 \text { days }\end{array}$ \\
\hline $\begin{array}{l}\mathbf{3}^{\text {rd }} \text { sitting } \\
(7 / 9 / 2019 \text { to } 13 / 9 / 2019)\end{array}$ & $\begin{array}{l}\text { 1. Karnadoopana with Lakshadi choorna } \\
\text { 2.Lakshadi guggulu (1-1-1) After food } \\
\text { 3. Tab. Sarivadi Vati-(1-1-1) After food. } \\
\text { 4.Chitrakadi harithaki lehya (1tsp-0-1tsp) After food }\end{array}$ & $\begin{array}{l}7 \text { days } \\
7 \text { days } \\
7 \text { days } \\
15 \text { days }\end{array}$ \\
\hline
\end{tabular}


Figure 1: After treatment (viewed through end-scope)



1. Otomycosis $90 \%$ cured.

2. Central perforation $80 \%$ healed.

3. Complete pain reduction.

\section{DISCUSSION}

In Otomycosis, mainly watery and purulent type of discharge is present which shows the condition of Paka. While removing the fungal mass, ulceration of external auditory canal is likely to happen. Considering these points Otomycosis can also be treated in the line of Dushtavrana.

Regarding Sadhyasadhyata, Acharya Sushrutha has mentioned that Vrana situated in Twaka and Mamsa and Vrana lying in Karna is Sukha Sadhya. ${ }^{(18)}$ In Uttaratantra, Acharya Sushruta considered Karnasrava itself as Sadhya roga.

Probable mode of action of drug used for Karnadoopana

Karnadoopana is a procedure, introducing medicated Dhooma (smoke) into the ears. It helps to dry ups the secretions in external auditory canal and inhibit the growth of microorganisms.

Lakshadi Choorna contains Laksha, Guggulu, Haridra and Nimba choorna. (Anubhutha yoga)

1. Laksha-has Kashaya, Tikta and Madhura Rasa which is called as Saumya Rasa. It pacifies Pitta. It is mentioned for Vranaropaka in Bhela samhita. ${ }^{(19)}$ It is a Vednashamana, Daha Prashamana, Shothahara and Krimihara dra- vya. ${ }^{(20)}$ Laksha Choorna is astringent, having analgesic and anti inflammatory property.

2. Guggulu -helps in relieving Shotha and does Lekhana Karma. Guggulu and Laksha are known to be having analgesic and anti-inflammatory properties.

3. Haridra -is having katu and Tikta rasa and ushna virya. It is having rooksha guna. It is helpful in wound healing. Charaka says-Haridra is lekhaneeya, kushthaghna and vishaghna.

4. Nimba patra choorna- has good antibacterial effect. Nimba is well known and described

As Kandughna, Kushthaghna and Krimighna. Nimba is Vayu and Akasha mahabhoota Pradhana. That is why its patra Dhooma may act on pyogenic bacteria staphylococcus aureus. This Nimbapatra Dhooma stops the multiplication of bacterial cell and dries up the intracellular fluid matrix in a bacterial cell by its panchabhautik properties i.e. rooksha, laghu, vishada and lekhana guna. This mechanism produces disturbance in bacterial cell's metabolism and hence resulting in bactericidal action of the dravya.

1. Nimbapatra Dhooma acts by inhibiting the growth of bacteria by killing them.

2. Sarivadi Vati- It is one of the medicines of Karnarogas explained by Baishajyaratnavali In Karnaroga Adhyaya.

3. Chitrakadi Harithaki Lehya-It is one of the Amapachana drug and having properties like mucolytic, antibacterial, anti-inflammatory, antimicrobial, antioxidant and immune modulator. So here I had taken the medicine because it helps in removing of abnormal secretions from Srothas like Karnavaha Srothas

4. Lakshadi Guggulu- It is one of the best Asthisandana drug and Shoolahara drug. It helps to heal tympanic membrane perforation.

\section{CONCLUSION}

Karnasrava (Otomycosis) is a disease which may lead to severe complications. Ayurvedic line of treatment gives useful result in the management of Karnasrava by improving general status. The mode of treatment was found to be cost effective, safe and easy to imple- 
ment. Lakshadi Karnadoopana for duration of 7 days and 3 sittings is sufficient for the treatment of the disease Karnasrava (Otomycosis), provided with proper Pathyapathya. If Vrana associated with Karnasrava, Dushtavrana Chikitsa can also be adopted in the management of Karnasrava.

In the management of the Otomycosis, Lakshadi Karnadoopana has shown better results. The duration of the treatment is short; hence, for reaching any definite conclusion, further long-duration studies are needed. Since the study has shown interesting results, it is recommended that the study can be carried out on a large number of patients with longer duration to evaluate and analyze the results.

\section{REFERENCE}

1. Mugliston T, O’ Donoghue G. Otomycosis - a continuing problem. Journal of Laryngology and Otology. 1985; 99(4):327-333. [PubMed] [Google Scholar].

2. Pontes ZBVDS, Silva ADF, Lima EDO, et al. Otomycosis: a retrospective study. Brazilian Journal of Otorhinolaryngology. 2009; 370. [PubMed] [Google Scholar]

3. Fasunla J, Ibekwe T, Onakoya P. Otomycosis in western Nigeria. Mycoses. 2008; 51(1):6770. [PubMed] [Google Scholar]

4. Kurnatowski P, Filipiak A. Otomycosis: prevalence, clinical symptoms, therapeutic procedure. Mycoses. 2001; 44(11-12):472479. [PubMed] [Google Scholar]

5. Pradhan B, RatnaTuladhar N, Man Amatya R. Prevalence of otomycosis in outpatient department of otolaryngology in Tribhuvan University Teaching Hospital, Kathmandu, Nepal. Annals of Otology, Rhinology and Laryngology. 2003; 387. [PubMed] [Google Scholar]

6. Munguia R, Daniel SJ. Ototopical antifungals and otomycosis: a review. International Journal of Pediatric Otorhinolaryngology. 2008; 459. [PubMed] [Google Scholar]

72(4):453-

7. Kaur R, Mittal N, Kakkar M, Aggarwal AK, Mathur MD. Otomycosis: a clinicomycologic study. Ear, Nose and Throat Journal. 2000; 79(8):606609. [PubMed] [Google Scholar]

8. Viswanatha B, Sumatha D, Vijayashree MS. Otomycosis in immunocompetent and immunocompromised patients: comparative study and literature review. Ear, Nose \& Throat Journal.2012; 91:114121. [PubMed] [Google Scholar]

9. Stern JC, Lucente FE. Otomycosis. Ear, Nose and Throat Journal. 1988; 67(11):804810. [PubMed] [Google Scholar
10. Pontes, ZB, Silva, AD, Lima Ede, O. Otomycosis: a retrospective study. Braz J Otorhinolaryngol. 2009; 75(3):367-370.Google Scholar | Crossref | Medline.

11. Ho, T, Vrabec, JT, Yoo, D, Coker, NJ. Otomycosis: clinical features and treatment implications. Otolaryngol Head Neck Surg. 2006; 135(5):787-791. Google Scholar | SAGE Journals.

12. Hurst, WB. Outcome of 22 cases of perforated tympanic membrane caused by otomycosis. J Laryngol Otol. 2001; 115(11):879-880. Google Scholar | Crossref | Medline.

13. Acharya JadavajiTrikamji., editor. Nibandhasangraha Commentary of Shri Dalhanacarya. 7th ed. 3-5. Vol. 20. Varanasi: Chaukhamba Orientalia; 2002. Sushruta, Sushruta Samhita, Uttara Tantra. [Google Scholar]

14. Acharya JadavajiTrikamji., editor. Ayurveda Dipika Commentary of Cakrapanidatta. Re-print ed. 3-5. Vol. 26. Varanasi, India: ChaukhambaSurbharatiPrakashana; 2008. Agnivesha. Charaka Samhita- Chi. [Google Scholar]

15. Acharya JadavajiTrikamji., editor. Nibandhasangraha Commentary of Shri Dalhanacarya. 7th ed. 8. Vol. 22. Varanasi: Chaukhamba Orientalia; 2002. Sushruta, Sushruta Samhita, Sutra. [Google Scholar]

16. Acharya JadavajiTrikamji., editor. Nibandhasangraha Commentary of Shri Dalhanacarya. 7th ed. 40. Vol. 21. Varanasi: Chaukhamba Orientalia; 2002. Sushruta, Sushruta Samhita, Uttara Tantra. [Google Scholar]

17. Bhargava KB. A short textbook of ENT. Diseases. P. L. Dhingra - Disease of Ear Nose \& Throat. John Jacob Ballenger-Disease of the Nose Throat \& Ear. Logan Tuner-disease of the nose throat and ear [Google Scholar

18. Vagbhata--Ashtanga Sangraha - Ut. With Indu Commentary29(26) [Google Scholar]

19. Sharma P, editor. 1st edition. Vol. 27. Varanasi: Chaukhamba Visvabharti; 2000. Bhela Samhita, ChikitsaSthana, VranaChikitsaAdhyaya; p. 469. [Google Scholar]

20. Bulusu Sitaram. Laksha. 1st edition. Vol. 1. Varanasi: Chaukhambha Orientalia; 2006. Bhavaprakash of Bhavmisra; p. 175. [Google Scholar]

\section{Source of Support: Nil \\ Conflict of Interest: None Declared}

How to cite this URL: Chaya C et al: A Single Case Study On Effect Of Lakshadi Choorna Karnadoopana In Otomycosis Associated With Otitis Media. International Ayurvedic Medical Journal \{online\} 2020 \{cited October, 2020\} Available from: http://www.iamj.in/posts/images/upload/4889 4893.pdf 